\title{
Pengaruh Penggunaan Pembelajaran Think Write Pair Shaire (TWPS) Berbantuan LMS terhadap Hasil dan Minat Belajar
}

\author{
Rakhmatul Ummah \& Rizalul Fiqry \\ Program Studi Pendidikan Fisika, STKIP Taman Siswa Bima \\ *Email: amumgi@gmail.com
}

Received: 16 November 2021; Accepted: 30 November 2021; Published: 19 Desember 2021

DOI: http://dx.doi.org/10.29303/jpft.v7i2.3129

\begin{abstract}
Due to the spread and increasing number of positive cases due to the COVID-19 virus in Indonesia Especially Sape, Bima NTB, the Ministry of Education and Culture (Kemendikbud) recommends ways to reduce the spread of the virus by conducting online learning, this study explores the effect of cooperative learning on student learning outcomes in terms of interst in learning. The cooperative learning model used is Think Write Pair Share (TWPS) assisted by a learning management system (LMS) to lear during pandemic. The LMS used is Schoology. This research is an experimental study using a pre-test post-test control group design model. The research subjects consisted of two groups, namely the experimental group and the control group. All groups were given a pre-test (an instrument to measure learning outcomes) and a learning interest questionnaire using the ARCS model (attention, relevance, self-confidence) with thirty-four questions, the experimental group was given treatment in the form of teaching using Schoology-assisted cooperative learning TWPS. The control group was given conventional learning, after treatment, all groups were given a posttest and a learning interest questionnaire. The last stage is a data processing and data analysis using ANCOVA, the result is that Schoology assisted TPS cooperative learning can improve student learning outcomes with a significance level of 0.005 .
\end{abstract}

Keywords: Think Write Pair Share; Learning Management System; Covid-19; Learning Outcomes; Learning interest.

\section{PENDAHULUAN}

Pendahuluan antara lain berisi latar belakang masalah, kesenjangan antara yang diidealkan dan yang senyatanya, didukung oleh teori dan penelitian mutakhir yang relevan tentang masalah, dan nilai baru penelitian yang merupakan inovasi. Bagian ini ditulis sebanyak maksimum $20 \%$ dari badan artikel.

Wabah virus corona (covid-19) yang melanda telah memberikan tantangan tersendiri bagi lembaga pendidikan. Kondisi ini mengharuskan siswa dan tenaga pendidik untuk tetap stay at home, bekerja, belajar dan melakukan aktivitas apapun di rumah (Jamaluddin, D. R., \& Paujiah, 2020). Peningkatan jumlah kasus positif di indonesia membuat Kementerian Pendidikan dan Kebudayaan (Kemendikbud) merekomendasikan cara untuk menurunkan penyebaran virus dengan melakukan pembelajaran secara online (Arifa, F. 2020). Hal ini secara tidak langsung mempercepat penerapan pendidikan 4.0 dan tuntutan kurikulum yang mengintegrasikan penggunaan TIK pada semua mata pelajaran untuk menciptakan pembelajaran yang inovatif dan kolaboratif, dimana keunggulan yang ditawarkan tidak hanya terletak pada faktor kecepatan dan kemudahan mendapatkan informasi atau sumber materi, namun beberapa fasilitas multimedia yang terdapat didalamnya dapat membuat proses pembelajaran menjadi lebih seru dan interaktif (Sulisworo, et al., 2020). Salah satunya dengan menggunakan bantuan aplikasi android mobile learning atau perangkat seluler sebagai alat bantu pembelajaran. 
Perangkat seluler merupakan teknologi informasi yang memungkinkan pembelajaran menjadi lebih menarik, interaktif dibandingkan yang lain sehingga muncul istilah Learning Management System (LMS) (Ummah, et al. 2020). Terdapat beberapa jenis LMS yang dapat dimanfaatkan dalam proses pembelajaran diantaranya adalah Schoology, Learnboos, Edmodo, Moodle dan lain-lain. Dibandingkan yang lain Schoology merupakan salah satu situs yang menggabungkan jejaring sosial dan LMS, berbentuk web sosial yang menawarkan pembelajaran sama seperti didalam kelas secara gratis (Wijayanti. 2017).

Salah satu model pembelajaran kooperatif yaitu Think Write Pair Share yang merupakan penggabungan Think Pair Share dengan Think Talk Write (Siregar, Y. I., \& Susito, H., 2017). Model pembelajaran kooperatif Think Write Pair Share dirancang untuk dengan memberikan siswa waktu untuk memikirkan topik yang diberikan, memungkinkan mereka untuk merumuskan ide individu dan berbagi ide dengan rekan. Dalam strategi yang dimodifikasi ini dalam permasalahan yang diajukan, siswa memiliki waktu untuk berpikir secara individu, menulis pemikiran mereka, serta bekerja berpasangan untuk memecahkan masalah, dan kemudian membagikan ide mereka (Suhartoyo \& Mukminatien, 2015). Pembelajaran kooperatif TWPS sangatlah cocok untuk pembelajaran fisika, dikarenakan fisika merupakan mata pelajaran yang memerlukan pemahaman daripada penghafalan, tetapi diletakkan pada pengertian dan pemahaman konsep, penyajian data secara matematis dan dapat diaplikasikan dalam kehidupan sehari-sehari (Sutarto, \& Palupi, R. 2014). Sehingga disimpulkan bahwa diperlukan suatu inovasi pembelajaran kooperatif dengan memanfaatkan kemajuan teknologi berbantuan LMS yang dapat membantu memudahkan kegiatan pembelajaran sehingga diharapkan menumbuhkan minat serta hasil belajar siswa menjadi lebih meningkat.

LMS yang digunakan dalam penelitian ini adalah Schoology, Schoology merupakan website yang memadukan e-learning dan jejaring sosial, memiliki konsep yang sama seperti Moodle, namun dalam hal e-learning Schoology mempunyai banyak kelebihan, dan menguntungkan dibandingkan menggunakan Moodle dikarenakan tidak memerlukan hosting dan pengelolaan. Schoology lebih user friendly. Tentu fiturnya tidak selengkap Moodle, namun untuk pembelajaran e-learning disekolah sudah sangat memadai (Slameto. 2010); (Sukanti. 2011). Kelebihan Schoology adalah tersedianya fasilitas attandance yang digunakan untuk mengecek kehadiran siswa, dan juga fasilitas analicy untuk melihat aktivitas siswa pada setiap course, assignment, discussion, dan aktivitas lain yang disiapkan untuk siswa (Ummah, R., \& Sulisworo, D. 2018).

Maka diperlukan strategi pembelajaran yang mudah dan efisien digunakan sehingga menghidupkan kelas dan menumbuhkan minat belajar, maka pembelajaran kooperatif yang cocok untuk hal tersebut (Ummah, R., \& Sulisworo, D. 2018). Sehingga proses pembelajaran akan berjalan efektif jika penggunaan LMS diintegrasikan kedalam pembelajaran kooperatif (Miftahul, H. 2015).

\section{METODE PENELITIAN}

Penelitian ini merupakan jenis penelitian eksperimen semu (quasi eksperimen) yang akan dibagi ke dalam tiga tahapan yaitu tahap persiapan, tahap pelaksanaan dan tahap akhir. Pada tahap persiapan terdapat beberapa kegiatan yang dilakukan antara lain melakukan observasi 
awal dengan mewawancara pendidik untuk mendapatkan informasi terkait variabel penelitian, studi literatur terkait variabel penelitian yang akan dikaji, menyusun proposal, menyusun teknis pembelajaran menggunakan model kooperatif berbantuan LMS (Schoology) serta instrumen yang akan digunakan untuk mendapatkan data penelitian. Melakukan uji validasi, uji coba instrumen, dan menganalisis hasil uji coba instrumen tersebut, serta menentukan sampel penelitian. Pada tahap pelaksanaan diterapkan Pretest Postest Control Group Design.

Kelompok eksperimen dan kelompok kontrol akan diberikan instrumen untuk mengukur hasil belajar (berupa soal) dan angket minat belajar model (ARCS) yang berisikan sebanyak 34 butir pertanyaan, kemudian kelompok eksperimen akan diberikan pengajaran dengan menggunakan model pembelajaran kooperatif Think Write Paire Share berbantuan LMS (Schoology) selama waktu yang ditentukan, sedangkan kelompok kontrol akan diberikan pembelajaran secara konvensional. Kemudian setelah proses pembelajaran selesai diberikan kembali instrumen pengukur hasil belajar dan angket belajar pada kedua kelompok. Untuk tahap akhir, dilakukan pengolahan data pretest dan posttest menggunakan ANCOVA. Untuk lebih jelas dapat dilihat pada Gambar 1 .

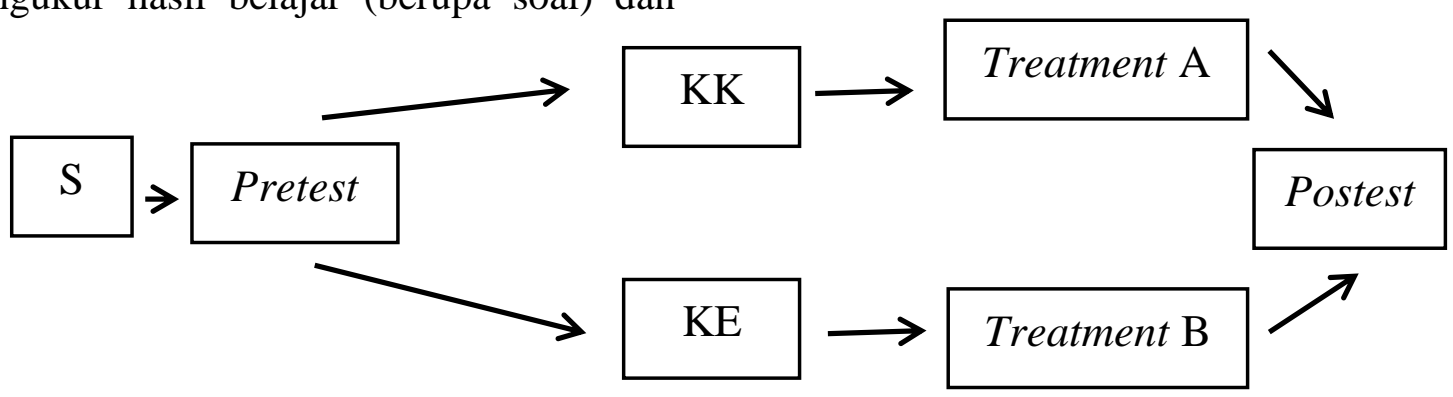

Gambar 1. One Group Pre test-Post test Design

Dari Gambar diatas, Ttreatment $A$ adalah Kelas Kontrol dan Treatment B adalah pembelajaran menggunakan bantuan aplikasi Schoology.

\section{HASIL DAN PEMBAHASAN}

\section{Hasil}

\section{a. Analaysis Demografis}

Penelitian ini dilakukan dengan menggunakan dua kelas sebagai sampel penelitian, yaitu kelas kontrol (Perlakuan A) dan kelas XI IPA 3 sebagai kelas eksperimen (Perlakuan B). Setiap kelas terdiri dari 29 siswa, persentase siswa laki-laki yang diteliti $11 \%$ dan siswa perempuan $89 \%$, perhitungan ini diperoleh dari jumlah siswa laki-laki sebanyak 9 orang dan perempuan 49 orang. Jumlah siswa laki-laki pada kelas eksperimen adalah 5 orang, dan jumlah siswa laki-laki pada kelas kontrol adalah 4 orang, sedangkan jumlah siswa perempuan pada kelas eksperimen adalah 24 dan jumlah siswa perempuan pada kelas kontrol adalah 25 siswa.

\section{b. Deskripsi Data}

Setelah proses penelitian dilakukan, maka proses terakhir adalah melakukan tes akhir (post-test) untuk mengumpulkan data penelitian, disertai dengan analisis deskripsi data yang diperoleh dari masing-masing dapat dilihat pada tabel 3 dan 4 . 
Table 3. Deskripsi data menggunakan Treatment A

\begin{tabular}{lccccc}
\hline & N & Min & Max & Mean & Stdv \\
\hline $\begin{array}{l}\text { Learning } \\
\text { Achievement }\end{array}$ & 29 & 55 & 90 & 72,5 & 6,423 \\
$\begin{array}{l}\text { Learning } \\
\text { Interst }\end{array}$ & 29 & 110 & 190 & 149.9 & 8,419 \\
\hline
\end{tabular}

Table 3. Deskripsi data menggunakan Treatment B

\begin{tabular}{lccccc}
\hline Item & N & Min & Max & Mean & Stdv \\
\hline $\begin{array}{l}\text { Learning } \\
\text { Achievement }\end{array}$ & 29 & 50 & 80 & 70,9 & 7,065 \\
$\begin{array}{l}\text { Learning } \\
\text { Interst }\end{array}$ & 29 & 103 & 140 & 121,5 & 10,806 \\
\hline
\end{tabular}

Dari dua tabel di atas terlihat bahwa kelas kontrol yang diberi Treatment B dan kelas eksperimen yang diberi Treatment A untuk hasil belajar dan minat belajar.

\section{c. Tes Uji Prasyarat Analysis \\ 1. Uji Normalitas}

Pengujian ini digunakan dalam dilakukan untuk mengetahui apakah yang diteliti berdistribusi normal atau tidak normal. Pengujian ini dilakukan pada kelas kontrol (Treatment A) dan kelas eksperimen (Treatment B). Dari hasil perhitungan uji normalitas untuk kelas kontrol disimpulkan bahwa sampel yang digunakan dalam penelitian ini berdistribusi normal, hal ini dapat dilihat dari nilai signifikansi pengetahuan awal (Pretest) $(0,577>00,05)$, minat belajar $(0,112>0,05)$, masing-masing lebih besar dari taraf signifikansi 0,05 .
Sedangkan perhitungan kelas eksperimen menyimpulkan bahwa sampel yang digunakan dalam penelitian ini berdistribusi normal, hal ini dapat dilihat dari nilai signifikansi pengetahuan awal (Pretest) $(0,174>0,05)$, minat belajar $(0,88>0,05)$, masing-masing lebih besar dari pada tingkat signifikansi 0,05 .

\section{Uji Homogenitas}

Hasil yang dipaparkan di atas menunjukkan bahwa setiap variabel tersebut bersifat homogen, dimana jika dilihat dari nilai signifikansi masing-masing variabel lebih besar dari taraf signifikansi 0,05 maka dinyatakan kelas yang digunakan sebagai kelas yang diteliti adalah homogen. Ditambah lagi jika nilai statistik Levene < Ftab maka dinyatakan kedua variabel homogen, dimana Ftab $=4,098$, sedangkan Fhit yang diperoleh untuk masing-masing variabel, adalah 3,351 untuk hasil belajar, 10,756 untuk minat belajar siswa.

\section{d. Ancova}

Analisis menggunakan uji ANCOVA digunakan untuk menyimpulkan pengaruh variabel bebas terhadap variabel terikat. Untuk mengetahui ada tidaknya pengaruh hasil belajar siswa dari posttest dengan minat belajar berikut adalah hasil perhitungan dengan menggunakan ANCOVA seperti terlihat pada Tabel berikut:

Tabel 5. The result of ANCOVA: Tests of Between-Subjects effects

\begin{tabular}{ccccccc}
\hline & & $\begin{array}{c}\text { Sum of } \\
\text { Squares }\end{array}$ & df & Mean Square & F & Sig. \\
& Between & 412,224 & 1 & 412,224 & 4,834 &, 031 \\
\multirow{2}{*}{ Minat } & Groups & & & & & \\
& Within Groups & 6310,763 & 74 & 85,281 & & \\
& Total & 6722,987 & 75 & & & \\
\hline
\end{tabular}




\begin{tabular}{ccccccc}
\hline & Between & 257,895 & 1 & 257,895 & 4,187 &, 044 \\
\multirow{2}{*}{ Postest } & Groups & & & & & \\
& Within Groups & 4557,895 & 74 & 61,593 & & \\
& Total & 4815,789 & 75 & & & \\
\hline
\end{tabular}

Tabel 6. Individual Parameter Significant Test (t statistical test) Treatment A

\begin{tabular}{cccccc}
\hline \multirow{2}{*}{ Model } & Unstandardized Coefficients & $\begin{array}{c}\text { Standardized } \\
\text { Coefficients }\end{array}$ & \multirow{2}{*}{$\boldsymbol{T}$} & \multirow{2}{*}{ Sig. } \\
\cline { 2 - 5 } & $\boldsymbol{B}$ & Std. Error & Beta & & \\
\hline Constant & 88,685 & 8,511 & & 10,420 & 0,061 \\
\hline Minat & & & & & \\
\hline Attention & $-0,023$ & 0,038 & $-0,149$ & $-0,618$ & 0,647 \\
\hline Relevance & 0,257 & 0,044 & 1,231 & 5,871 & 0,107 \\
\hline Confidance & 0,107 & 0,054 & 0,572 & 1,979 & 0,298 \\
\hline Satisfied & $-0,407$ & 0,092 & $-1,205$ & $-4,440$ & 0,141 \\
\hline
\end{tabular}

Table 7. Individual Parameter Significant Test (t statistical test) Treatment B

\begin{tabular}{cccccc}
\hline \multirow{2}{*}{ Model } & Unstandardized Coefficients & $\begin{array}{c}\text { Standardized } \\
\text { Coefficients }\end{array}$ & \multirow{T}{*}{$\boldsymbol{T}$} & \multirow{2}{*}{ Sig. } \\
\cline { 2 - 5 } & $\boldsymbol{B}$ & Std. Error & Beta & & \\
\hline Constant & 61,779 & 6,725 & & 9,187 & 0,012 \\
\hline Minat & & & & \\
\hline Attention & $-0,035$ & 0,040 & $-0,341$ & $-0,864$ & 0,479 \\
\hline Relevance & 0,089 & 0,035 & 0,572 & 2,530 & 0,127 \\
\hline Confidance & $-0,092$ & 0,047 & $-0,650$ & $-1,949$ & 0,191 \\
\hline Satisfied & 0,110 & 0,049 & 0,700 & 2,261 & 0,152 \\
\hline
\end{tabular}

\section{e. Perhitungan Kontribusi Variabel}

Untuk menghitung kontribusi variabel bebas terhadap variabel terikat digunakan besaran korelasi dengan mengalikan beta pada persamaan regresi. Hasil perhitungan kontribusi efektif dan relatif untuk kelas eksperimen dan kelas kontrol ditunjukkan pada tabel berikut.

\begin{tabular}{ccccc}
\hline & Beta & Corelation & $\begin{array}{c}\text { Efective } \\
\text { Corelati } \\
\text { on }\end{array}$ & $\begin{array}{c}\text { Relative } \\
\text { Contributi } \\
\text { on }\end{array}$ \\
\hline $\begin{array}{c}\text { KK } \\
\text { (Treatme } \\
\text { nt A) }\end{array}$ & $\begin{array}{c}0,07 \\
\text { KE }\end{array}$ & 0,543 & $22,44 \%$ & $49 \%$ \\
\hline $\begin{array}{c}\text { Treatme } \\
\text { nt B) }\end{array}$ & 0,58 & & & \\
\hline
\end{tabular}

Menggunakan perhitungan berdasarkan analisis regresi linier berganda, persentase kontribusi efektif dan persentase kontribusi relatif, kontribusi efektif
(Treatment A) adalah 22,44\%, dan kontribusi relatif (Treatment A) adalah 49\%. Sedangkan kontribusi efektif (Treatment B) sebesar $34,62 \%$ dan kontribusi relatif sebesar $51 \%$. Gabungan sisa sumbangan efektif dari kelas eksperimen (Treatment B) dan kontrol (Treatment A) sebesar 42,94\% merupakan pengaruh dari variabel eksternal.

\section{Pembahasan}

\section{a. Pengaruh hasil belajar dan minat belajar \\ Hasil penelitian ini menunjukkan} bahwa analisis kovarians dan analisis linier berganda yang dihitung berdasarkan setiap konstruk angket minat ARCS dalam penelitian yang digunakan untuk mengukur pengaruh minat belajar siswa terhadap hasil belajar pada penelitian menunjukkan bahwa hipotesis diterima. Terdapat hubungan yang positif dan signifikan antara minat dengan 
hasil belajar siswa (Ermelinda, Benge 2017). Minat belajar sangat besar pengaruhnya terhadap hasil belajar karena jika materi pelajaran yang dipelajari tidak sesuai dengan minat siswa maka siswa tidak akan belajar dengan baik. Jika belajar tidak dibarengi dengan minat maka siswa akan malas dan tidak akan mendapatkan kepuasan dalam mengikuti pembelajaran. Semakin tinggi minat belajar siswa akan berpengaruh terhadap hasil belajar yang diperoleh siswa, siswa yang memiliki minat belajar yang rendah cenderung mendapatkan hasil belajar yang lebih rendah karena siswa yang mendapatkan hasil belajar yang lebih rendah tidak menyukai materi, pembelajaran atau cara guru menjelaskan. di kelas tidak menarik dan kurang menyenangkan, sehingga siswa cenderung tidak mau belajar di rumah atau mendengarkan penjelasan guru dengan seksama di kelas.

\section{b. Pengaruh Pembelajaran TWPS Terhadap Hasil Belajar}

TWPS (Think Write Pair Share) merupakan kombinasi pembelajaran kooperatif TPS (Think Pair Share) dan TTW (Think Talk Write). Penggunaan model pembelajaran Think Pair Share dapat meningkatkan hasil belajar siswa (Suhartoyo \& Mukminatien, 2015). Dalam penelitian lain juga dikatakan bahwa terjadi peningkatan hasil belajar siswa melalui pembelajaran Think-Talk-Write (TTW). Guru dapat menggunakan strategi ThinkTalk-Write (TTW) sebagai alternatif pembelajaran untuk meningkatkan hasil belajar siswa (Karina, M, R., Syafrina, A., Habibah, Sy., 2017). berikut pernyataan tersebut menunjukkan bahwa model pembelajaran TPS dan TTW berpengaruh terhadap proses dan peningkatan hasil belajar siswa.

\section{c. Pengaruh penggunaan LMS terhadap hasil belajar}

Pembelajaran harus dipersiapkan secara terencana dan sistematis untuk menghasilkan proses dan hasil belajar yang maksimal. Selain itu, layanan pembelajaran di LMS akan memberikan alternatif ketika tidak dapat melaksanakan pembelajaran secara tatap muka, dapat diselenggarakan melalui LMS berbasis Website, baik dengan penawaran pembelajaran campuran maupun pembelajaran sepenuhnya online (Adrika, K., 2019). siswa tertarik menggunakan LMS karena mereka percaya bahwa pembelajaran di LMS dapat membantu dan mendukung kegiatan akademik seperti mengerjakan tugas, membaca materi, dan memberikan komentar tentang LMS (Prasetyo, T., et al. 2021); (Juhary, J. 2014). Salah satu LMS yang dapat diterapkan dalam pembelajaran adalah Schoology. Schoology tersedia dalam bentuk aplikasi smartphone yang dapat menggabungkan jejaring sosial dan LMS. bahwa Schoology adalah salah satu LMS berupa web sosial yang menawarkan belajar sama seperti di kelas secara gratis dan mudah digunakan seperti media sosial Facebook. LMS Schoology mampu meningkatkan hasil belajar karena kemudahan penggunaannya (Hermansyah, et al. 2021). Penggunaan Schoology berpengaruh signifikan terhadap hasil belajar siswa (Azizah et al., 2017). Yang lain juga menyatakan bahwa penggunaan Schoology berpengaruh signifikan terhadap hasil belajar (Kusumantara et al., 2017). Beberapa fitur yang dimiliki LMS Schoology untuk memudahkan pengguna seperti Courses digunakan untuk membuat mata kuliah, Groups digunakan untuk membuat grup, Resources sebagai sumber belajar yang diinput oleh dosen untuk calon guru seperti tugas, ulangan/kuis, file/link, diskusi, halaman, dan album. Selain itu, aplikasi ini juga memiliki fasilitas 
Atsignance yang digunakan untuk mengecek kehadiran calon guru saat perkuliahan. Berdasarkan uraian tersebut, artikel ini bertujuan untuk mengetahui tingkat kemandirian belajar calon guru fisika melalui penerapan pembelajaran berbasis LMS: Schoology di tengah wabah COVID19.

\section{PENUTUP}

Hasil analisis menunjukkan bahwa terdapat pengaruh penggunaan pembelajaran kooperatif Think Write Pair Share berbantuan LMS terhadap hasil belajar siswa. Schoology merupakan LMS yang mudah digunakan karena mudah digunakan ditambah dengan fasilitas penunjang yang terdapat di dalamnya, apalagi jika digabungkan menggunakan model pembelajaran kooperatif.

\section{UCAPAN TERIMAKASIH}

Terimakasih Kementerian Riset, Teknologi, dan Pendidikan Tinggi Republik Indonesia dengan Skema Penelitian Dosen Pemula, Tahun 2021 yang telah mendanai penelitian ini.

\section{REFERENSI}

Jamaluddin, D. R., \& Paujiah. (2020). Pembelajaran Daring Masa Pandemik Covid 19 Pda Calon Guru: Hambatan, Solusi dan Proyeksi. Karya Tulis Ilmiah UIN Sunan Gunung Djjati Badung, 1-10.

Arifa, F. (2020). Tantangan Pelaksanaan Kebijakan Belajar dari Rumah dalam Masa Darurat covid-19. Jakarta: Kajian Singkat Terhadap Isu Aktual dan Strategis.

Sulisworo, D., Ummah, R., Nursholih, M., \& Raharjo, W. (2020). The Analysis of The Critical Thingking Skills Between Blended Learning Implementation: Google Classroom and Schoology. Universal Journal of Educational Reseach 8(3)B, 33-40.

Ummah, R., Suliswiro, D., \& Raharjo, W. (2020). The Effect of Informal Cooperative Activity Through Online Learning on The Understanding of Physics Concept. Universal Journal of Educational Research, 69-77.

Wijayanti. (2017). Pengembangan Perangkat Blended Learning Berbasis Learning Management System Pada Materi Listrik Dinamis. Jurnal Ilmiah Pendidikan Indonesia. Vol. 6 (1).

Siregar, Y. I., \& Susito, H. (2017). Pengaruh Think Pair Share Write Berbasis HYbrid Learning Terhadap Keterampilan Metakognitif, Berpikir Kreatif, dan Hasil Belajar Kognitif Siswa SMAN 3 Malang. Jurnal Pendidikan Biologi Indonesia, Vol (3) 2 .

Suhartoyo, E., Mukminatien, N., (2015).The Effect of Toulmin's Model of Argumentation Within TWPS Strategy on Students' Critical Thingkin on Argumentative Essay. Jurnal Pendidikan Humaniora, Vol (3) 2, 143-153.

Sutarto, \& Palupi, R. (2014). Media Video Kejadian Fisika Dala Pembelajaran Fisika di SMA. Jurnal Pembelajarn Fisika.

Slameto. (2010). Belajar dan Faktor- Faktor yang Mempengaruhinya. Jakarta: Rineka Cipta.

Sukanti. (2011). Penilaian Efektif Dalam Pembelajaran Akuntansi. Jurnal Pendidikan Akuntansi Indonesia, Vol. IX No.1, 74-82.

Ummah, R., \& Sulisworo, D. (2018). Pengaruh Pembelajaran Kooperatif Informal Think Pair Share Berbantuan Schoology Terhadap Hasil Belajar . Seminar Nasional Edusaintek FMIPA UNIMUS, 340344. 
Miftahul, H. (2015). Cooperative Learning Metode, Teknik, Struktur, dan Model Penerapan . Yogyakarta: Pustaka Belajar.

Ermelinda, Benge (2017). Hubungan Antara Minat dan Motivasi Belajar Dengan Hasil Belajar IPA Pada Siswa SD. Journal of Education Technology. Vol. 1 No. (4) pp. 231- 238.

Karina, M, R., Syafrina, A., Habibah, Sy., (2017). Hubungan Antara Minat Belajar Dengan Hasil Belajar Siswa dalam Mata Pelajaran IPA pada Kelas V SD Negeri Garot Geuceu Aceh Besar. Jurnal Ilmiah Pendidikan Guru Sekolah Dasar FKIP Unsyiah. Volume 2 Nomor 1, 61-77.

Adrika, K., (2019). Think-Talk-Write: Strategi untuk Meningkatkan Hasil Belajar Matematika Siswa; JNPM (Jurnal Nasional Pendidikan Matematika). Volume 3, No. 2, September 2019.2 DOI: http://dx.doi.org/10.33603/jnpm.v3i 2.1995

Prasetyo, T., et al. (2021). Kepercayaan dan Kepuasan Penggunaan LMS Mahasiswa Selama Pembelajaran Daring. JURNAL BASICEDU Volume 5 Nomor 4 Tahun 2021 Halaman 2330 - 2338 Research \& Learning in Elementary Education https://jbasic.org/index.php/basicedu

Juhary, J. (2014). Perceived usefulness and ease of use of the learning management system as a learning tool. International Education Studies, 7(8), 23-34. https://doi.org/10.5539/ies.v7n8p23

Hermansyah, et al. (2021). Kemandirian Belajar Calon Guru Fisika Melalui Pembelajaran Berbasis LMS: Schoology. Indonesian Journal of STEM Education, Vol. 2 No. 1, 2020: 34-42.

Azizah, S. R., Suyatna, A., \& Wahyudi, I. (2017). Pengaruh Penggunaan ELearning Dengan Schoology
Terhadap Hasil Belajar Siswa. Jurnal Pembelajaran Fisika, 5(2).

Kusumantara, K. S., Santyadiputra, G. S., \& Sugihartini, N. (2017). Pengaruh ELearning Schoology terhadap Hasil Belajar Simulasi Digital dengan Model Pembelajaran SAVI. Jurnal Pendidikan Teknologi dan Kejuruan, 14(2). 